\title{
DOCUMENTS
}

\author{
T. M. Parssinen \\ I. J. Prothero
}

\section{THE LONDON TAILORS' STRIKE OF 1834 AND THE COLLAPSE OF THE GRAND NATIONAL CONSOLIDATED TRADES' UNION: A POLICE SPY'S REPORT}

The Grand National Consolidated Trades' Union of 1834 marked an important turning-point in British labour history. It was the culmination of five years' activity on behalf of general unionism, and its failure dealt a decisive blow to the goal of labour unity. It was based on the London trades, and especially the tailors, who went out on strike in April $1834 .{ }^{1}$ The failure of their strike led to the withdrawal of the tailors and later of the cordwainers from the Consolidated Union, and inevitably to its collapse. The importance of the tailors' strike is clear, but evidence about it is scarce. One of the chief sources is a series of reports made by a hitherto unknown police informer, from which we give a selection.

The present document is important and very unusual in consisting of a commentary on events at the rank-and-file level. It includes fortythree of ninety-one pages of reports made in 1834 by a single police spy that are filed in the Public Record Office, Home Office papers, eightyone of them in 64/15, six in 52/24, and four in 64/19. The HO 64/15 reports are not only on the tailors but include reports on various radical organisations. From the reports on the tailors we have selected only some which pertain to the strike, and especially to the relationship between the tailors and the Consolidated Trades' Union. All these but two are from $64 / 15$. The reports are not filed in chronological order,

\footnotetext{
1 For trade-union developments in these years, see S. and B. Webb, The History of Trade Unionism (London, 1920), ch. 3; G. D. H. Cole, Attempts at General Union (London, 1953); R. W. Postgate, The Builders' History (London, 1923), chs $3-5 ;$ W. H. Oliver, "Organisations and ideas behind the efforts to achieve a general union of the working classes in the early 1830's" (unpubl. Ph.D. thesis, Oxford, 1954); id., “The Consolidated Trades' Union of 1834", in: Economic History Review, Second Series, XVII (1964-65), pp. 77-95; A. E. Musson, British Trade Unions 1800-1875 (London, 1972), ch. 4. For the tailors, see E. P. Thompson, The Making of the English Working Class (London, 1963), pp. 25557 ; F. W. Galton, Select Documents illustrating the history of Trade Unionism, I : The Tailoring Trade (London, 1896).
} 
and many are undated, but most can be placed on the basis of internal evidence and the day of the week, which is almost always noted. The author is never given.

Scattered through the Home Office papers in various series, mainly 40,52 and 64, is a large number of reports for the years 1830-33, forming a continuous series, in the same handwriting and with the same style and type of content. They mostly deal with the National Union of Working Classes, and are a major source for anyone studying that body. They contain a great deal of information, and indicate that the informant was known to and trusted by many of the leading radicals, and was a member of the committee. The reports are perceptive and accurate, and the spy is not an agent provocateur.

Usually the reports are unsigned, and when the name was given it has been erased. There were several spies in the NUWC, including Samuel Dean, Clements and the notorious Popay, who was exposed in 1833. It is often assumed that some of these reports are by Popay. ${ }^{1}$ But they cannot all be, as it is known that Popay was not employed at the time of the earlier reports, being appointed a policeman on 3 September $1831 .^{2}$ The theory that the reports are not all by the same person is only compatible with the fact that they are in the same handwriting by regarding them not as the originals but as copies all made by the same clerk in the Bow Street Police Station. But this is only speculation, and it is much simpler to accept that they are originals in the informer's hand, especially as on the back they often bear the name of the recipient, John Stafford, Chief Clerk at the Bow Street office. There is no evidence at all that any of the reports are by Popay, and it was never so alleged at the Select Committee investigation of his case.

There is other evidence to suggest that the reports are all by the same person. All through there is a special familiarity with radical groups in East London. Several times the informant indicates that he is closely acquainted with men, like Thomas Preston, who were members of Arthur Thistlewood's group. Twice he recalls details of the Cato Street conspiracy, and in one report he says he first got to know Stafford at the time of that affair. ${ }^{3}$ One of the earliest reports is endorsed on the back "Inform" of Abel Hall $1 f$ per week". ${ }^{4}$ In another report the

1 E.g., J. H. Wiener, The War of the Unstamped (London, 1969); P. Hollis, The Pauper Press (London, 1970), pp. 43, 52, 53, 110, 116, 117, 133, 148, 176, 197, 198, 267.

2 Select Committee appointed to inquire into the Matter of the Petition of Frederick Young, and others [Parliamentary Papers, 1833, XIII], p. 453.

3 Public Record Office, London, HO 64/11, reports dated 20 and 25 November 1830.

Ibid., 13 August 1827. 
informant says that his name is advertised in the Poor Man's Guardian with Preston and others to attend a meeting in Islington; the names in the Guardian are Preston and Hall. ${ }^{1}$

Abel Hall is mentioned several times in reports of informers in Thistlewood's conspiracy. He was present in the loft at Cato Street the night they assembled, but managed to escape as the soldiers and magistrates closed in. He was soon arrested, along with fourteen others. Stafford interviewed him, and found him disposed to tell all he knew. But Hall was not needed for the trial of Thistlewood and four others, as the prosecution had the testimony of Robert Adams, another conspirator who had a change of heart and was willing to testify against his erstwhile fellow plotters. Hall swore a deposition, outlining his activities on 8 May $1820 .^{2} \mathrm{He}$, Thomas Preston and three others were later released, and Hall managed to retain the confidence of the London ultra-radicals. He apparently sent regular reports to Stafford throughout the 1820's, but only a few of these were passed on to the Home Office and survive. Similarly not all his reports in the 1830's were passed on.

There are reports on the Consolidated Union in 64/15 from two informers. One of these is known to be G. M. Ball, of the Gardeners' Lodge. The other, from whose reports this document is drawn, is the same as the NUWC spy. The handwriting is the same. He reports on the same groups as before, including the NUWC. He is familiar with Thomas Preston; he is a tailor, as was Hall; and, in one of the reports not included in the document, the informant explains the tailors' modified initiation procedure. In giving an example of the oath, he uses initials which are probably his own: "The Words 'In the presence of Almighty God I A- H-Taylor do promise to keep \&c' is substituted as I have before stated." And so we are confident as to the accuracy of the document, as Abel Hall was a trustworthy reporter.

The tailoring trade was typical of London industry in being unmechanised, organised mainly in small businesses, and characterised by homework. ${ }^{3}$ By the end of the eighteenth century there were a number of

${ }^{1}$ HO 64/12, undated report filed before report for 11 September 1832; Poor Man's Guardian, 8 September 1832, p. 528.

${ }^{2}$ HO 44/6. See also T. M. Parssinen, "The Revolutionary Party in London, 1816-20", in: Bulletin of the Institute of Historical Research, No 45 (1972), pp. 266-82.

3 The following account of the tailoring trade is based on these sources: Gorgon, 26 September 1818 , pp. 148-51; 3 and 10 October, pp. 157-60, 161-62; Select Committee on Artizans and Machinery [Parliamentary Papers, 1824, V], Reports of Minutes of Evidence (F. Place), pp. 44-46; Labourer's Friend and Handicrafts Chronicle, October 1821, p. 311; Weekly Free Press, 3 July 1830; Man, 
large employers in the West End producing high-quality, bespoke garments, but even these tended not to have a permanent labour force. Loss of working time was consequently a problem for tailors, both in waiting for work and travelling to get it, and in the seasonal character of the trade, with twice as much work from April to June as from August to October. Even in a prosperous year, a tailor could be out of work for five months. To meet these problems some public houses early in the eighteenth century became "houses of call", where tailors who wanted work registered their names and waited, and masters applied when they needed men.

The demand for labour in the brisk period of the year kept up earnings and tailors were able to afford benefit clubs. These and the houses of call developed into trade unions. The seasonal nature of the work strengthened the unions' position and put a premium on unified action. The societies could, and did, make high wage demands in April and then collect funds from their members for relief payments to be made during the later period of under-employment. Unemployment relief was very unusual among London trades, who on the whole tended to rely on "tramping", ${ }^{1}$ and is a measure of the tailors' strength. Moreover, many of the top employers, in Westminster, were favourable to the men's organisation, and granted requests for wage rises to keep a monopoly of the best men.

The shortage of labour created by the wars with France from 1793 further raised the tailors' wages, to a peak in 1813 of $36 /$ - per week for six twelve-hour days. They enforced the twelve-hour day to share out work. And so by the end of the wars the tailors were in a very strong position, with about twenty-five houses of call that had monopolies of the best workmen; for if any man was complained about three times by masters, he was excluded from the house. But each wartime rise was gained in the face of growing opposition from some masters, especially small ones, and so from the 1790's the tailors' organisation grew more secret and military, controlled by the "Town", the powerful secret executive of five. The tailors had the strongest of all the London com-

24 November 1833, p. 159; 1 and 8 December, pp. 161, 173; Crisis, 30 November 1833, pp. 109-10; Pioneer, 15 March 1834, pp. 253-54; 19 April, pp. 309-10; 3 and 10 May, pp. 329-30, 334-35, 338, 343; True Sun, 29 April 1834, p. 1 ; 6 May, p. 2; 9 May, p. 1; Place Collection, Set 41, f. 17; Set 51, ff. 246-47; Set 52, ff. 87-89, British Museum; W. Lovett in London Dispatch, 6 July 1836, ibid., Set 56, f. 10; Place to Longson, 28 May 1834, British Museum, Add. Mss 35149, f. 293; Webb Collection of Trade Union Manuscripts, A XIV, ff. 44-66, London School of Economics; Red Republican, 16 and 23 November 1850, pp. 169-70, 177-79. "For tramping, see E. J. Hobsbawm, "The Tramping Artisan", in: Economic History Review, Second Series, III (1950-51), reprinted in his Labouring Men (London, 1965), ch. 4. 
binations, and it took the masters thirty years to break it down.

However, troubles developed even during this prosperity. The men's insistence on a high standard of work and the heavy fines led to exclusion and bitterness, and the appearance from 1793 of an important number of excluded men, called "dungs" as opposed to the superior "flints". The former were less skilled, often worked at lower rates and so undercut flints, and above all were often paid by the piece instead of by the day. Under piece-work it was harder to control the rate of work, and the result was often over-work, with the consequent shortage of work for others. The dungs developed some organisation of their own, and the demand for labour during the wars prevented this schism from being too serious, but this changed with the depression at the end of the wars. Thereafter all organisation among the dungs collapsed and they undercut the flints. The latter maintained the 1813 day-rate, but employment and therefore actual earnings were declining.

A more serious threat that developed during the war was the rapid increase in the number of units of production to meet the growing demand. This mainly took the form of small "chambermasters" working at home, but some new large businesses arose as a result of government contracts, and towards the end of the war they began to employ cheaper female labour, a practice long prevented by the men and bitterly resented now. These capitalist developments continued after the war, to the detriment of the men. Firms with contracts for government, army and police work employed cheap female and child labour. By the early 1820's much of the trade was in the hands of "slop-shops" and "show-shops", selling inferior and, in the case of the former, readymade articles. If they employed labour directly, it was cheap labour; and as the owners were often not tailors, they employed foremen, who sometimes ruled in a tyrannical way. But usually they did not have large premises and so gave orders to small masters, and because they could place orders they enforced competitive tendering.

The small masters or "sweaters" had to undercut one another. Many of them were chambermasters, working at home and employing no-one but their families. Many others employed women and children, paying them from $3 /-$ to $8 /-$ per week, often for a working day from 6 a.m. to 10 p.m. And many others acted as middlemen and gave work to journeymen to be done at their own homes at low rates. Homework meant losing more time in travel and bearing the cost of firing for irons, candlelight and sewing trimmings, which in a proper workshop were borne by the employer. Such workmen might earn 3/6d to $4 /-$ in a day, but sometimes $2 /-$ or even $1 /$ - for fourteen to sixteen hours' labour. They were forced to use their wives' and children's labour to help them. Low earnings led workmen to compensate by overwork, which 
even further increased the competition. These journeymen and chambermasters lived in a state of unrelieved poverty, in which long periods without work alternated with periods of intensive work night and day.

The cheaper, ready-to-wear sector grew rapidly in relation to the bespoke side, and the flints inevitably suffered from competition and loss of work. Periods of unemployment reduced earnings, and even though the old day-rate of $6 \mathrm{~d}$ per hour remained, this was in fact often only $5 \mathrm{~d}$ through various devices. The depression of 1826 severely drained the flints' unemployment funds. A strike in 1827 against female labour was beaten, the first that the tailors had lost in at least sixty years. The power of the flints was broken in the late 1820 's by schism, a further drain on funds, and the growth of show-shops, slop-shops and sweaters. Another unsuccessful strike in 1830 emphasised their loss of power.

In the early 1830's the tailors' weakness and the need for regrouping were obvious. Their chance seemed to come with the economic recovery of 1833. Efforts at union began at least as early as September, and in November the Grand Lodge of Operative Tailors of London was founded. ${ }^{1}$ The problems of the trade and the remedies were clear enough. Because of the weakness created by the hostility between flints and dungs, and even among the flints themselves, because of preference given to more senior members in obtaining work, all tailors must be united in one unexclusive association. Uniformity was impossible when there was so much home work, and so all work would have to be done on employers' premises. This would also prevent poor women from doing work cheaply at their homes. Because some tailors had no work while others were working excessively, hours must be limited in order to share work and reduce unemployment. ${ }^{2}$ Piece-work led to overwork and lack of uniformity, so should be abolished. Distress should be reduced by raising the day-rate. These were the aims of the new union.

The reduction of hours would mean that earnings would actually be reduced for the top men, those paid at the full rate and working a full twelve-hour day. But the aim of the union was equalisation, and the need to end the great fluctuations in employment seemed far more important than possible maximum earnings. To outsiders, the insistence on day-work instead of piece-work seemed to mean that men would be paid the same however hard they worked. But in most of the old trades

1 Man, 24 November 1833, p. 159; 1 and 8 December, pp. 161, 173; Crisis, 30 November 1833, p. 110; Poor Man's Guardian, 4 January 1834, p. 428.

2 This limitation "will be the distribution of the surplus hours of the old system. It will give employment to one-sixth more hands during the four summer months, and one-third during the other eight months, a desideratum of the greatest importance." G. Batson in True Sun, 1 May 1834, p. 3. 
there was a well-established traditional rate of work, a "stint" that was well understood, and there was a stigma attached to slacking. The London tailors had their "Log", the amount of work a skilled man could manage, so day-work did not mean a slower pace but the avoidance of over-work. Some older and inferior workmen would not be able to keep up with the Log, and the union accepted that they should be paid at a lower day-rate provided that a union committee gave its approval in each case.

The events of 1834 mark an important stage in the history and decline of the trade, and it must be emphasised that the character, objectives and actions of the union are wholly explicable in terms of the tailors' experiences and past history, and need not be attributed to outside influences.

The significance of the strike was far wider than the tailoring trade. The tailors had been instrumental in organising the Consolidated Trades' Union, which they had conceived as an agency for inter-union aid. Tailors' delegates had attended the London Co-operative and Trade Union Congress in October 1833..$^{1}$ The London Grand Lodge of Tailors called the meeting of delegates from town and country that met from 13 to 19 February and founded the Consolidated Union. Of the thirty delegates, five were London tailors, and one of them, MacDonald, was in the chair. The tailors' committee submitted preliminary propositions, resolutions based on them, and regulations for the union, all of which were unanimously adopted. The tailor John Browne was made grand secretary of the new union. ${ }^{2}$ The bulk of the union's membership came from London, and the two largest member-groups were the London tailors and cordwainers. Tailors like George Petrie were active missionaries for the union, and of the twenty-eight towns that had lodges, eight had lodges of tailors and six of cordwainers.

The Consolidated Union must be related to several factors. First, 1834 was a year of economic recovery, when the position of labour was stronger and hopes of wage-rises were well-founded. Efforts to raise wages in good times were typical of the older artisan trades, from whom its membership was largely drawn. Second, joint action and help among such trades was traditional enough. Third, such action was always increased when a large or spectacular dispute arose and evoked widespread feelings of solidarity; in this case the Derby silk-weavers' dispute, with the resultant enthusiasm and relief committees, provided an emotional focus for the union. Fourth, ideas of general union were particularly widespread in the early 1830's; and there were examples

1 Man, 13 October 1833, p. 108.

2 Pioneer, 22 February 1834, p. 216; 8 March, pp. 234-35; Poor Man's Guardian, 31 May 1834, p. 134; Oliver, "The Consolidated Trades' Union", loc. cit., p. 80. 
in the National Association for the Protection of Labour of 1830, and the Operative Builders' Union of 1833, both of which had a federal structure that the GNCTU copied. Fifth, many of the leaders of the union came from the London United Trades' Association, a group of producers' co-operatives in which the tailors had been involved. ${ }^{1}$ This contribution helped strengthen the idea of co-operative production. Sixth, the union's main support in London came from those declining and militant trades of tailors, shoemakers and silk-weavers. ${ }^{2}$ The four chief aims of the union are not surprising: mutual support over strikes; benefit payments (sick and superannuation); employment of out-ofwork members; and co-operative production during strikes.

The union grew rapidly after February. At the end of March the sentence on the six Dorchester labourers threatened the whole tradeunion movement; but its result was to reinforce trade-union solidarity, strengthen the Consolidated Union, and bring it radical support. At the head was the five-member Executive, clearly a copy of the "Town" of the London tailors. Below this were to be the District Committees composed of delegates from all the trades in an area belonging to the union. But in fact only two were formed, at London and Birmingham. Yet from the start the Executive was in a weak position, with the union still immature and the opposition strong from both the public and the employers. The Executive proved unequal to their task, even failed to keep records properly, ${ }^{3}$ and virtually abdicated leadership of the whole union to the London District Central Committee. This Committee, with sixty-three delegates from twenty-one trades, including builders' representatives, was the active body. It organised the great demonstration on 21 April against the Dorchester labourers' conviction, with help even from country delegates. ${ }^{4}$ The Committee was much more familiar and acceptable to the London trades than was the Executive.

1 Most of the deposits at Owen's Labour Exchange were brought by individuals, but there also arose in connexion with it a number of societies, each consisting of members of a single trade, which produced goods for exchange in the bazaar. They used their funds to employ out-of-work members, and found the Exchange gave a ready market for the goods. These societies together formed the United Trades' Association, which in July 1833 took over from Owen's committee a leading share in the running of the Exchange. The UTA drew support from the same trades as joined the Consolidated Union, and actually suspended its meetings in February 1834 as many of its members were involved in the foundation of the union. For the UTA, see Crisis, April 1833 to March 1834; W. H. Oliver, "The Labour Exchange Phase of the Co-operative Movement", in: Oxford Economic Papers, New Series, X (1958).

${ }^{2}$ HO 64/15, account of receipts and expenditures.

3 Crisis, 12 April 1834, p. 4; 26 July, p. 128.

4 Ball to Roe, 5 and 15 April 1834, and anonymous undated report in HO 64/15; Oliver, "The Consolidated Trades' Union", p. 84. 
The Executive, as well as others, felt a great respect for Robert Owen, a man who had given years and a fortune to efforts to end poverty, had devoted himself to industrial reorganisation in 1833, and in 1834 had supported the GNCTU and come out against the Dorchester labourers' conviction. By March Browne was in correspondence with him. ${ }^{1}$ Owen's "Institution of the Industrious Classes" in Charlotte Street was always available for use by trade unionists. His lectures were always well-attended, and he identified himself with industrial movements in the North. Moreover, a certain William Neal, an Owenite, helped Browne with letters, accounts, and circulars of the tailors' union. At the tailors' request, Neal drew up the documents for the February Congress, with the proviso that they should be approved by Owen, and thereafter wrote the initiation ceremony, general laws, petitions and letters of the Consolidated Union. ${ }^{2}$ The various addresses of the Executive suggest Owenite influence in their general tone, plans to open a general bank for the working classes, abolish money and replace great employers by Boards of Labour and Committees of Industry, and their offer to negotiate with the governments of Europe and America in order to establish a terrestrial paradise. ${ }^{3}$

A further characteristic of the Consolidated and other unions was their reliance on Owenite periodicals, the fate of the earlier co-operative movement as well. Late in 1833 the tailors were encouraged and supported by the Man, run by the Owenites Lee and Petrie, and Crisis, originally owned by Owen and now edited by his associate James Smith. To these was added the Pioneer, edited by the Owenite James Morrison, which became the official organ of the Consolidated Union. Morrison and Smith strongly supported the trade-union movement of 1833-34, especially the moves to general union. They were especially aroused by Derby into hostility to employers and government, and advocacy of very far-reaching social changes, in which trade unions were to be the instruments. These "syndicalist" opinions steadily divided them from Owen, and this growing antipathy has been emphasised by most historians who have written about the Consolidated Union. ${ }^{4}$

1 Browne to Owen, 5 March 1834, Owen Papers, No 679, Co-operative Union Library, Manchester.

Neal to Owen, 18 April 1834, Owen Papers, No 685. Neal was Chairman of the Amalgamated Tailors in the 1860's.

Pioneer, 19 April 1834, p. 307; 24 and 31 May, pp. 369, 380; Crisis, 19 April 1834, pp. 15-16; 24 May, p. 54.

"Oliver, "The Consolidated Trades' Union"; Webbs, History of Trade Unionism, pp. 114-50; G. D. H. Cole, The Life of Robert Owen (London, 1966), pp. 283-85; M. Cole, Robert Owen of New Lanark (New York, 1953), pp. 199-204; G. D. H. Cole, Attempts at General Union, pp. 122-50; F. Podmore, Robert 
While Morrison and Smith propounded an increasingly violent theory of class conflict, and sought to turn the union into the instrument whereby the "producers" would win a general strike against the "non-producers", Owen refused to abandon his strategy of class reconciliation and non-violence. Yet at the same time, Morrison and Smith's theories also tended to divide them from trade-union opinion. Few historians have emphasised this even more fundamental split between the Owenite spokesmen and the rank-and-file members. However penetrating the social analyses of Smith and Morrison, however acute their suggestions and blueprints for total social reorganisation, for most trade unionists they were as irrelevant as the utterances of the Executive. While a few leaders saw the union as an agency of social transformation, the ordinary members saw it as a way to broaden their financial base, and thus strengthen their position in individual strikes to improve wages and working conditions.

When the tailors went out on strike they expected, and were promised, financial support from the London Central Committee of the union. They themselves had been among the heaviest contributors to the Derby men. ${ }^{1}$ Instead they received denunciations from their supposed champions, who saw the tailors' strike as an irresponsible deviation from their far-reaching plans for the union. Owen specifically advised against using the union as a support for local strikes:

"The attention of the unionists ought now to be withdrawn from all their little petty proceedings about strikes for wages, or, in plain English, at what weekly sum in money, continually varying in value, they shall sell themselves, their birthright, and their happiness, and the birthright and happiness of their posterity, to their masters and the non-producers". 2

Smith and Morrison claimed that even if the tailors won, it would only make clothes more expensive and so improve their position unjustly at the expense of their brother unionists. They had in fact totally misunderstood the objectives of the strike, and persisted in seeing it solely as an attempt at higher wages, not realising that the claims resulted from clear understanding of developments in the trade and were

Owen: A Biography (New York, 1907), pp. 447, 450; J. F. C. Harrison, Robert Owen and the Owenites in Britain and America (London, 1969), pp. 211-14; G. D. H. Cole and A. W. Filson, British Working Class Movements: Selected Documents, 1789-1875 (London, 1965), pp. 270-75; J. Saville, "J. E. Smith and the Owenite movement 1833-34", in: Robert Owen: Prophet of the Poor, ed. by S. Pollard and J. Salt (London, 1971), pp. 115-38.

1 Pioneer, 8 February 1834, p. 200; 31 May, p. 381.

2 Crisis, 19 April 1834, p. 14. 
really meant to bring about industrial reform. This very comprehensive attempt to remove the distress and abuses of the trade was regarded by Smith as destructive, while Morrison called it "unsocial". Both condemned "partial strikes", and Morrison did not believe that the tailors could win. He saw the only solution in a general strike. ${ }^{1}$ Even the Executive condemned individual strikes, claiming erroneously that "this association has not been formed to contend with the masterproducers of wealth and knowledge for some paltry advance in the artificial money-price in exchange for their labour, health, liberty, natural enjoyment, and life". ${ }^{2}$

In great contrast was the unequivocal support given the tailors by the leading radical periodicals, the True Sun and the Poor Man's Guardian. They saw trade unions as organisations to defend the poor, and possible bases of support for radicalism. As such, they accepted them as they were, unlike Smith and Morrison, who wished to change them in accordance with their social theories. ${ }^{3}$ The real press champions of trade unionism in 1834 were the daily evening True Sun and Sunday Weekly True Sun, not the Crisis or Pioneer. ${ }^{4}$

Abel Hall had ceased sending regular reports to John Stafford in October 1833, when political agitation waned. But in February 1834 Stafford asked him to resume his duties. Acting on these instructions, Hall joined the tailors' union at No 2 Branch Lodge. The initiation ceremony of the tailors' union combined ritual forms similar to those used by freemasons with elements of economic analysis and propaganda (Doc. I). The total strength of the London tailors' union was variously estimated at 9-13,000. By May there were thirty-one lodges, most of which were located in the West End, where the better-paid men worked in bespoke shops. The branch lodges met every Thursday. Each had a president, vice-president, secretary and delegate. The last attended the weekly meeting of the Grand Committee and reported the

1 "We depend for deliverance entirely upon grand and national movements, and not upon the limited struggles of individual trades". Pioneer, 3 May 1834, p. 330. Smith favoured embracing "the whole mass of producers, before hostilities are commenced". Crisis, 3 May 1834, p. 29.

${ }^{2}$ Crisis, 24 May 1834, p. 54.

3 Thus Morrison typically hailed the tailors' schemes for co-operative production as "the beginning of a new era - the beginning of the redemption of man".

4 On 4 May a full meeting of delegates of the London trades recommended exclusive support for the True Sun. They also urged unionists not to buy the Times and to do their best to check its sale. Weekly True Sun, 11 May 1834, p. 290; Place Collection, Set 51, f. 72 . In 1833 a hundred plasterers had walked in procession to the True Sun office and each bought a copy. Man, 29 September 1833, p. 99. 
proceedings to his branch lodge. Every Wednesday was the general meeting of all members, in Grand Lodge. Every Monday was a special meeting of the Grand Lodge for the initiation of new members.

Hall sent several reports in March. Further help for the striking Derby silk-weavers was agreed on, and $£ 200$ was sent to help them begin co-operative production. Meanwhile the efforts to strengthen the tailors' organisation did not progress well. Hall reported: "Our Funds are very 'Low' and many are dissatisfied by the calls for so much subscription." 1 The tailors' committee took the lead in encouraging the London Central Committee to call a public meeting on 24 March at Owen's Institution about the Dorchester labourers. The main speakers were Owen and radicals like the parson Arthur Wade, the journalist William Carpenter, John Savage, and also some unionists like Duffey, James Morrison, and the coopers' leader, Abraham. Twelve thousand packed in and agreed to send a petition to both Houses of Parliament, requesting a select committee of inquiry into the Consolidated Trades' Union, and an address to the King, praying for mercy for the six Dorchester labourers. Some speakers, including Morrison and Abraham, called for simultaneous meetings, a general strike, and the convening of an anti-parliament. However, nothing came of these plans, and the tailors began to plan their own strike. ${ }^{2}$

In spite of the weakness of the union and the depletion of their funds, the tailors hastily drafted a list of demands for presentation to their masters in April, the beginning of the brisk period in the trade. While Hall claims that the tailors had the full support of the London Central Committee for their strike (Doc. II), such a categorical promise seems unlikely. When the strike began, the Consolidated Union was slow to help, while the cordwainers complained bitterly that it had been decided that they would strike first, and the tailors had pre-empted them. ${ }^{3}$ During the first two weeks of April the tailors, like unionists in

${ }^{1}$ HO 64/19, report dated 18 March.

2 Pioneer, 29 March 1834, pp. 267-70; Poor Man's Guardian, 29 March 1834; Hall's reports in HO64/15. Ideas of a general strike were circulating in the early 1830 's, but hitherto they had been mainly political in conception, notably in Benbow's Grand National Holiday and Congress of the Productive Classes. It was usually combined with plans for simultaneous meetings and a national convention. But the failure of the Derby weavers and then the Dorchester sentence led to the spread of the idea as a trade-union weapon, to defeat the alliance of government and employers. All through April, Morrison's Pioneer called for a general strike, but the moderate view prevailed in the Central Committee. See I. J. Prothero, "William Benbow and the Concept of the 'General Strike" ", in: Past \& Present, No 63 (1974), pp. 132-71, and T. M. Parssinen, "Association, Convention, and Anti-Parliament in British Radical Politics, 1771-1848", in: English Historical Review, LXXXVIII (1973), pp. 504-33.

${ }^{3}$ True Sun, 24 May 1834, p. 1. 
other London trades, were still engaged in raising relief funds for the Derby strikers and petitioning the King on behalf of the Dorchester labourers, as well as planning their own strike (Doc. III). By the end of the month, the rank-and-file were clearly anxious for the strike to begin, whilst the leaders were trying to restrain them (Doc. IV).

The London Central Committee seems to have agreed to support the tailors when the strike began with a fund raised by loans from other trade unionists in the Metropolis (Doc. V). In addition, the tailors tried to strengthen themselves during the strike by co-operative production of garments for sale by the union itself (Doc. VI). This was a familiar tactic among the London trades, as the sale of goods lessened the drain on funds. But in the early 1830's the tailors had also found that cooperative production was a partial solution to the problem of unemployment. There had been several tailors' co-operative societies in these years that employed some of their members, and two had flourished as contributors to Robert Owen's National Equitable Labour Exchange.

On 25 April, the tailors' union issued a circular to all masters which set forth their demands. The True Sun of 4 June stated that 1,000 men were able to return to work when their employers agreed to the men's demands, and that another 1,000 left London to seek work in the country. But most master tailors were adamant. On 29 April, they met at Willis' Rooms, where they voted to reject the unionists' demands and to recruit strike-breakers. ${ }^{1}$ At the tailors' houses of call, the strikers were obliged to attend regular "call times" at intervals from 9 a.m. to 9 p.m. (Doc. VIII). This was to prevent any men from doing work secretly, as absentees were fined for non-attendance. ${ }^{2}$

Once the strike began, the tailors were denounced by the entire press, with the exception of a few radical journals. The tailors' action was inevitably seen as part of a general combination, and their leading part in the founding of the Consolidated Trades' Union underscored this charge. The tailors were accused of tyranny and violence towards nonmembers and non-strikers, and of seeking equal wages for all, regardless of individual skill. It was alleged that their demands, if conceded, would raise the price of clothing enormously. The Times was particularly hostile to unions in general, and to the tailors especially. It rejoiced in the defeat of the Derby men, and supported the master tailors, urging them to defeat the strike by importing German workers. Brougham, the Lord Chancellor, also castigated unionists at the outset

1 The Times, 30 April 1834, pp. 2, 6; True Sun, 30 April 1834, p. 1.

2 Undated report in $\mathrm{HO} 64 / 15$. 
of the tailors' strike. ${ }^{1}$ Rowland Detrosier, the London radical, responded to the tailors' enemies (Doc. IX), and the union issued "An Appeal to the Public on Behalf of the Journeymen Tailors of the Metropolis", published in the True Sun of 12 May, which attempted to answer its opponents' charges (Docs X and XVIII).

By the end of the first week of the strike, the tailors had acquired premises. They soon opened business there to sell directly to the public, and by the next week several hundred tailors were said to be employed in co-operative production. ${ }^{2}$ However, according to some newspaper reports, strike pay on 4 May for the second week was only $7 / 6 \mathrm{~d}$ or $8 /-$ instead of 10/-, which produced dissatisfaction. Some tailors went back to work in the City, although the West End remained solid. ${ }^{3}$ Perhaps because of this shortage of funds, on 5 May the Executive of the Consolidated Union ordered a levy of $1 / 6 \mathrm{~d}$ on all of its members to support the striking tailors (Doc. XI). This was not, however, well supported.

Meanwhile Hall's branch lodge moved from the Roebuck to the larger White Magpie, where the delegate was now Freestone instead of Taylor (Doc. XII). By the end of the second week of May, the tailors were very much on the defensive. At a meeting of the union at Owen's Institution they passed resolutions which were meant to answer the continuing attacks on them in the press. The tailors denied that the price of clothes would be much affected if their demands were met, and they were at pains to stress that the 6/- day-rate was only meant to apply to fully competent men; aged and inferior workmen would receive less. ${ }^{4}$ Contrary to the strikers' expectations there was no pay at all for the third week of the strike, beginning 12 May (Doc. XIII). On Tuesday 13 May Hall's branch lodge split, with one group, including Hall, joining a branch lodge at the Bell in Smithfield while the other group stayed at the Magpie (Doc. XIV).

The striking tailors agreed to negotiate with the masters beginning 14 May, presumably because of the weak and deteriorating condition of the union. A stumbling-block was that the masters preferred piecework and felt that under day-work they would not get a satisfactory rate of work. The union attempted to counter this in a circular issued on $16 \mathrm{May}$, in which they asserted that the union would enforce a fixed rate of work. ${ }^{5}$ Meanwhile these negotiations dragged on (Doc. XVI).

1 The Times, 29 April and 1 May 1834, p. 3; 9 May, p. 3; 28 May, p. 5; 30 May, p. 4 ; Mirror of Parliament, 1834, II, pp. 1314-16; Hansard, Third Series, XXIII, cc. 98-103.

2 Poor Man's Guardian, 10 May 1834, p. 107; Pioneer, 10 May 1834, p. 338.

${ }^{3}$ Morning Herald, 5 May 1834; True Sun, 13 May 1834, p. 1.

4 Pioneer, 17 May 1834, p. 357.

${ }^{5}$ Doc. XV, handbill in $\mathrm{HO} 64 / 19$. 
The tailors continued to hope for financial support, but received only a pittance from the Central Committee. By 20 May, about a thousand tailors had seceded from the union and gone back to work on the masters' terms (Doc. XVII). To add to their miseries, the tailors discovered that their funds had been embezzled, and their co-operative workshop robbed (Doc. XIX).

By the end of the third week of May, the tailors apparently reached an agreement in their negotiations with the masters to return to work on the old terms on Monday 26 May (Docs XVIII and XX). However, the Masters' Committee seized the opportunity to crush the tailors' union. On 27 May they met and voted by 532 to 8 to refuse to re-employ the men until they had signed the "document", abjuring trade-union membership forever. ${ }^{1}$ This was unacceptable to many men. ${ }^{2}$ No doubt recourse to the document prolonged the strike, and introduced a new element into it. The document alarmed other trades, for it portended an assault on trade unionism generally (Doc. XXI). Hence the meetings of the London Central Committee at the Rotunda, beginning on 26 May, and a furious denunciation of the document by the Executive, printed in the Weekly True Sun on 25 May: "Let no man or woman from one end of the Kingdom to the other, sign this document." In this new crisis, the idea of the general strike reappeared (Doc. XXIII).

From the last week of May to 2 June, the tailors who remained on strike waited and hoped for relief from the Consolidated Union (Docs XXII, XXIV and XXV). On 2 June the Central Committee recommended that all trade union members in work contribute one day's wages per week, and that all tailors in work contribute 1 - per day to the strikers (Doc. XXVI). But this was not widely honoured, and the financial situation of the union continued to deteriorate (Doc. XXVII). By 4 June only 5,000 of the original 9,000 tailors still remained out on strike. $^{3}$ At a meeting on 9 June of all the London trades, Owen and the Executive of the Consolidated Union tried to rally support for the tailors, whose strike was now critical in the face of the militant antiunionism taking hold among the masters in other trades (Doc.XXVIII). But this was too little, too late. Most of the original strikers had gone back to work, and those who remained out denounced their leaders for having mismanaged the strike. The strike dragged on, with minimal support from the Consolidated Union (Docs XXIX and XXX). On 22 June, the final blow was struck when the London Builders' Union refused to assist the tailors, no doubt because the builders were preparing

1 The Times, 26 May 1834, p. 5; True Sun, 4 June 1834, p. 1.

2 True Sun, 24 May 1834, p. 1.

3 Ibid., 4 June, p. 3. 
for their own coming struggle (Doc. XXXI). The tailors responded by seceding from the Consolidated Union (Doc. XXXII).

The tailors' failure and their subsequent withdrawal from the Consolidated Trades' Union gave it its "mortal wound". ${ }^{1}$ The Operative Cordwainers, the second largest member union, angry with both the tailors and the Executive, withdrew at the end of June to conduct their own unsuccessful strike. ${ }^{2}$ The final demise of trade unionism in London came in August and September with the defeat of the builders and the break-up of their union. ${ }^{3}$ Although the Consolidated Union lingered on until August 1835, it was no more than a relic. Its power and its promise had been shattered by the tailors' strike. As the union collapsed, Smith reflected that the tailors' strike "proved to possess a more dissolving, decomposing virtue than any other chemical ingredient of which the Union is composed". 4

After the 1834 strike, the tailoring trade continued to decline, with the spread of piecework, sweating, homework and cheap labour. The tailors played very little part in the trade-union activity of the rest of the decade, though they did play a leading part in Chartism. Some houses of call remained in the West End, and the "honourable" men there earned twice as much as the sweated men. In 1843-44 a final attempt was made to rally the tailors into union, based on the old houses of call. ${ }^{5}$ As in 1834 the aims were uniformity of rates, equalisation, and the end of homework. But its impact was limited, and 1843 marked the beginning of a rapid decline in the position of the honourable men in the West End. Though they remained somewhat better off than those further east, all were sinking to the appalling condition revealed by Mayhew and others in 1849-50. ${ }^{6}$

We have faithfully reproduced the original text, including Hall's many

1 According to Smith in Crisis, 12 July 1834, p. 109.

2 Pioneer, 26 June 1834, p. 420; Poor Man's Guardian, 12 and 26 July 1834, pp. 182, 197; Weekly True Sun, 6 July 1834, p. 354.

3 For accounts of this dispute, see Poor Man's Guardian and Weekly True Sun, August and September 1834.

4 Crisis, 14 June 1834, p. 76.

5 For conditions and activity in the early 1840's see English Chartist Circular, I, p. 205; II, pp. 5-6, 10-11; Northern Star, November 1843 through April 1845; Place Collection, Set 53, ff. 89, 127, 149-50.

- Northern Star, 18 March 1848, p. 2; 25 March, p. 2; Reynolds's Political Instructor, 2 February 1850 , p. $98 ; 6$ April, p. 175 ; G. J. Holyoake and R. Leblond, The Appeal of the Distressed Operative Tailors to the Higher Classes and the Public (London, 1850) ; H. Mayhew, London Labour and the London Poor (London, 1861-62), II, pp. 297-335; The Unknown Mayhew, Selections from the Morning Chronicle 1849-1850, ed. by E. P. Thompson and E. Yeo (London, 1971), pp. 181-227. 
grammatical and spelling errors. We have inserted editorial notations only in the few places where Hall's meaning would be unclear without them. Transcripts of Crown-copyright records in the Public Record Office appear by permission of the Controller of Her Majesty's Stationery Office.

Since I last wrote having been desired to attend to the "Trades Union" I found 'from Neesom ${ }^{1}$ who is a Taylor and very active among them as well as from several others who belong to it that in the Taylors Lodges who are the most numerous they are very particular in who they admit in consequence of having discovered that Policemen in disguise and others who are known to be Spies have tried to be "Initiated" into their Lodges and they will not now admit anyone who is not recommended by two "Brothers" who become so after they have been initiated and who know the party to be only of the Trade he professes. The Trades Unions have been established for some Months both in London and the Country and have much increased in both by nearly all Trades joining them. There are Carpenters, Bricklayers, Painters, Coopers, Cabinet Makers, Taylors and others in great numbers whose object is to raise a fund to support all Trades who belong to them in a Strike for Wages, to oppose all tyrannical Masters who are insolent to or resist any of their Workmens commands, to form themselves in their separate trade into bodies who will also form their own plans as to not Working for any Master who employs any other but Union Men and to oppose all systems of tyranny. For this purpose they have established Lodges similar to Free Masons and are sworn to maintain their Rights. The Rotunda in Black Friars Road is the principle or Grand Lodge and there also the Delegates from all parts of London and the Country meet. $^{2}$

1 Charles Hodson Neesom (1785-1861) was a tailor by trade who grew up in Scarborough, but came to London in 1810 where he became a Spencean and was nearly involved in the Cato Street conspiracy. He was active in the National Union of Working Classes, the tailors' union and the "war of the unstamped". Later he was a leading Chartist. Neesom knew Abel Hall from radical activities in the NUWC, and perhaps even from the post-war period.

2 The Rotunda had become the main radical meeting-place in London in 1830 , when it was leased by Hall's friend, the notorious republican and infidel publisher Richard Carlile, for political and theological discussions. The large theatre could be hired for all manner of public meetings, including for a while the NUWC, the tailors' Grand Lodge, and later the London Central Committee of the GNCTU. 
Monday evening last was and is Weekly the night for Taylors being initiated and I having been much persuaded by Neesom and Dove who proposed me went there $w[h]$ ere there was during the evening at least three thousand Taylors met. On going in there are two persons sitting who take down the name of the person to be admitted and the two who propose him and he is then ordered into a Room adjoining the large theatre which is very closely kept out of view either to wait while others are being made or until about 100 is assembled to be made. 130 was in the number I was among and previous to entering you are given a piece of string to tie your Hat to the upper button hole of your Coat and you are to Blind your eyes with a Handkerchief. At three loud knocks at a door inside which is answered without A Question is asked who it is who is wishing to interrupt our Great Lodge and the Answer is given that 130 good Men and who are without wish to enter to be made Members of their Grand Lodge and we are led Blindfold into the large Theatre where after order is obtained by loud knockings on the Floor the President either reads or rehearses several passages from the Psalms the Creed and the Gospels, all of which are selected as bearing on the Equality of Man and his right to oppose tyranny. Several Verses of a Union Song is then sang by the Brothers previously present and we are addressed as strangers for us to say whether we are willing to solemnly swear on our oaths to keep the Unions Secrets and to maintain them at the risk our lives to which we answer yes, and after a long address is spoken as to the Slavery Working Men have for years endured by the tyranny of Governments of all ages and the Masters employing Workmen by their combining to extract from them and their families their labour and bread we are ordered to kneel down to place our right hand on our naked left breast and our left on a stool before us on which is part of a leaf of the bible, but which we do not see. At this moment by a given motion of the President (which he after we are sworn shows us) all the Brothers present about 1500 loudly clap their hands and stamp their right foot once which is very loud indeed. We are then ordered to untie our handkerchiefs which discovers the Gas nearly extinguished. The President and Vicepresident behind him standing on a table with White Surplices on and Red Sashes round them and each has a Bible in his hand. Just before them is a Black Ground Transparency well light and on which is painted the perfect Skeleton of a Man. The President then takes a Sword in his hand the point of which he directs your attention first to the Skull and then to the heart the Arms, Legs and Body and in a short address goes to prove that when a Man is in work and in full vigour he soon becomes a skeleton by being tyrannized over by his Governors and Masters who employ him who rob him of substance - themselves to live in luxury on his Vitals. Over the head or 
Skull is inscribed Beware of your latter end, to which he directs your attention by stating that such end will soon by yours if you do not by Uniting prevent it and that if you after you are sworn do anything to injure the Union or be a Traitor to it Death will surely be your reward. There are also 8 Brothers who have naked Swords in their hands and wear red Sashes and several others who carry large Wooden Axes and Battle Axes and who surround this Skeleton and the President with his Sword and Vice with his go round to each person saying and at the same time putting the edge to your neck and taking your left hand in his what are you, the answer is a Taylor. he then says you are willing to swear to protect the Unions to the risk of your life to which you answer I will. The right hand being still on your left breast you then return your left hand to the Paper and being again darkened by the Officers or Tilers who stand close to hear you the President order each to repeat after him the Oath, which is I most solemnly swear that to my life's end I will protect and act upon and with the Laws and Brothers of the Trades Unions in any what that I will never reveal their Laws or secrets to any one, that I will never write or cause to be written or printed any of their proceedings or secrets, but will do all I can to discover any one who does and to assist in all my power every act they do So help my God. This being done we rise and are told we are now Brothers, that our Monthly Subscriptions would be One Shilling and that as the Union at Derby had been requested by the Masters to sign a Paper to return to their work on grounds derogatory to their principles and had nobly refused it was intended to further assist them by each member giving S1/- as well as getting what they could from non Members. ${ }^{1}$ I should state that on entrance to be initiated we pay Seven-pence. We were then told that to know any Member the Universal Sign was by placing the Right hand thumb and finger to the top on the left side of your waistcoat and carry it from thence across the body to the right thigh and if it was not answered by the same signal on the reverse side the Party so asked was no member. That every trade had its own signs to enter their lodges and that ours was on our approaching the door at which the first Tiler stood with a drawn Sword you are to use the right hand Sign and say slowly to him A. On getting to the second you use the same sign and say $Z$. You then are admitted to the Lodge where an open Bible is laid on the Table on which you are to place your right hand open from thence to your left breast and making an obesiance to the President and Vice you take your seat. He stated also that near

1 This refers to the famous device of the "document" in which employers made employees sign a declaration that they would not belong to a trade union. It was a tactic already used by builders in the North in 1833, and was widely used in the confrontation atmosphere of 1834 . 
10,000 were already Members of our Union the Grand Lodge of which would meet on Wednesday night at Eight $\mathrm{O}^{\prime} \mathrm{Clock}$ and that Branch Lodges were held at most of the Houses of Call at the West End of Town and at the Sun in London in London Wall, the Kings Head in St. Pauls Chain, the Ship in Lime St. and at the Three Lords in the Minories for the City who all corresponded and acted with the Grand Lodge and after two more Union verses of a Song was sung to the tune of God save the King and the President had said The Grace of our Lord \&c he stated that the Lodge was dissolved and we separated at Twelve O'Clock.

On Wednesday evening at $8 \mathrm{O}^{\prime}$ Clock I again attended and having passed the above signs entered the large theatre which at that time had about 1200 Taylors in it. The Floor was not in anyway decorated as above, but there was a table at which the Secretary to deliver Cards and receive Monies for them and Subscriptions. About $\frac{1}{2}$ past Eight the President who is a Taylor named Woodford, the Vice ${ }^{\mathbf{1}}$ and Brown the Warden of the Lodge having we proceeded to business the first of which was to place Woodford on the table with his Surplice and Sash has had al the Vice and to read the Minutes of the last Meeting which was done by Gutheridge who has acted as Secretary for sometime, but has resigned and from which it appears that a dispute having arisen sometime ago between him - Gutheridge, Duffey and Petrie it was referred to the General Committee who met on Friday night last to decide what steps to recommend. The Committee of all Trades are chosen from the body of the Union in their own Lodges and meet privately. Ours met on that night at the Blue Posts a house of call for Taylors in Brewer St. Golden Square and there decided that as Duffey had made charges against Gutheridge he should be suspended for three Months, but in Six weeks if he made an Apology he should be reinstated. Duffey, Gutherie and Petrie are the same persons who caused much confusion in the National Union, ${ }^{2}$ and this decision caused a very great confusion all the night by each of their partys proposing and reproposing Resolutions condemning each, so much so that no business was done, but I find that on Monday next Six Delegates from our trade upwards of Nine Thousand of whom belong to us are to go through England to Initiate mem-

1 I.e., vice-president. Hall, through unfamiliarity, has the names wrong. The president was James Woodham, the secretary Robert Guthrie, soon to be succeeded by John Browne.

2 I.e., National Union of Working Classes. Guthrie, William Duffey and George Petrie were all ultra-radicals, who were bitterly opposed to the more moderate leadership of Hetherington, Cleave and Watson. By 1833, all three had either quit or been expelled from the NUWC, and they looked instead to trade unions as the means of working-class emancipation. 
bers and Concentrate our Union and that other trades are doing the same. I find also that at several Shops at the West End the Men have struck to their Masters who would either "insult or not agree to our Union Plans" to regulate the work and the Men have thrown themselves on the Protection of the Union who have received them. The Confusion existed up to one O'Clock when the Lodge was dissolved, to meet again next Monday and Wednesday nights. I tried to get a copy of our Private Laws and the Laws of the Trades Unions generally, but the Secretary had none by him they being all sold and as I do not wish to be seen too forward I did not Press my wanting it, but will get them and send them as soon as possible. During the night 2812 Taylors met here and we separated at half past One.

Thursday Feby. 27th. 1834.-

II

On Wednesday evening I attended the Grand Lodge of the Taylor Trades Union at the Rotunda, at which about 1200 Taylors met. After the usual ceremony of opening the Lodge had been gone through George [sic; John] Brown the Grand Secretary read the minutes of the last Meeting which were confirmed. He then stated that as Lord Melbourne had not written an Answer to the Deputation who waited on him on last Sunday as he had promised to do he had been ordered to write his Lordship to know what the King had done as to the Six Convicts and that he had that day received a letter from Lord Howick which he read and which stated that his Majesty had not yet given any orders on the subject, at which a great deal of disapprobation was expressed, but he stated that the Central Committee of all the trades Unions was then sitting to determine on what we should next do in their case and that that would be made known to us at our Branch Lodges. Six of our Committee attended with Brown and stated that the Central Committee of all the Trades in London had agreed that our trade should from being the largest in number Strike First and that their Funds should assist us if we wanted them. The Plan is that as at this time of year our trade is mostly called into action we should strike about the middle of this Month - April of which notice is to be given to all the Branch Lodges. That all our Work is to be day work, that no man is to work more than 10 Hours $\mathrm{p}^{\mathbf{r}}$ day for which he is to be paid $8 \mathrm{~d} \mathrm{p}^{\mathbf{r}}$ hour, that from the first Monday in April to the last Saturday in July he is to be at his work from 7 in the Morning to 6 in the evening and the remaining 8 Months in the year from 8 to 5 leaving 1 hour for refreshment and not to work in any shop unless well ventilated and 
comfortable to his health. That no Master be allowed to pick his Men, but to go through the book which is to be one throughout the trade as the names stand ${ }^{1}$ and no Apprentice to be bound before he is 13 years of Age nor remain so after 18, and this is to extend 4 Miles from Covent Garden Market. The Bye Laws which he read are the same in substance and are in a stage of printing for us. As soon as I can get them I will send them. A Deputation from the Cordwainers waited on us to know what we meant to do as to the Six Convicts and they were told as I above state as to the Central Committee Sitting. Bills were Posted at the Rotunda as to the Second Meeting of the Unions to take place to day in Charlotte St Rathbone Place ${ }^{2}$ on the Six Convicts, but from what we were requested by Brown and from what I learnt from him I shall attend my Branch Lodge - the Roebuck in Aldgate to night and Report to morrow. We are also requested to attend a Brothers Funeral on Sunday next at two O'Clock and to assemble in Finsbury Square. A letter from Bradford in Yorkshire was read wishing us to send a Delegate there to initiate which was referred to the Committee and this being the only business the Lodge was closed about Eleven O'Clock.-

Thursday April 3rd 1833 [sic; 1834]

\section{III}

On Wednesday evening I attended the Grand Lodge of the Taylors Trades Union at the Rotunda, at which about 1200 Taylors attended and a great deal of anxiety prevailed as to when we should strike. The Lodge having been opened in the usual form about Nine O'Clock Brown the Head Secretary read the Minutes of the last Meeting which were confirmed and a letter which was that day brought to him by a special Delegate from Derby stating that their funds would be quite exhausted this week and that it would be impossible to hold out any longer unless

1 This refers to the practice at tailors' houses of call of inscribing the names of members seeking work in a book. When a master sent to the house for men, he did not choose them, but had men sent to him in the order that names were inscribed in the book, so that those who had been waiting longest received work first. But at some of the tailors' houses there were two books, and those who had been members for a longer time were on the first book and always received priority in finding work. This had resulted in antagonism among the organised flints, and it was a prime objective of the United Order of Tailors that there should be a one-book system.

2 This was Owen's "Institution of the Industrious Classes", where the Owenites had their meetings and regular lectures, and where were situated the National Equitable Labour Exchange and the Miscellaneous Lodge of the Consolidated Union. 
they were further assisted as the Masters were assisted by the Government. The Central Committee had sent him back with $£ 30$ and we as well as all the Trades were particularly requested to pay our Derby Levy and to enter into Subscriptions at our Branch Lodges to assist and keep them up as on this their Strike would depend a great deal the fate of the Union. He stated also that the Committee had sent a Delegate with $£ 30$ to the Wives and Families of the Six Convicts and had also determined that a Levy of $2 \mathrm{~d}$ should be immediately made on every Brother throughout all the Unions to place them above the taunts of a Tyrannical Government and that that sum would be quite sufficient. ${ }^{1} \mathrm{He}$ also stated that the Central Committee of Trades were still deliberating what to do as to Petitioning the King or to get the Men back and all the Petitions left at Branch Lodges of all the Trades for signatures or anywhere else is ordered to be sent to the Hercules Pillars Lincolns Inn Fields by Saturday night as the Central Committee were to determine on Monday what the Unions should do. He read the new Articles 34 in numbers which are to be submitted to the Branch Lodges for inspection or amendments and stated that all the Branch Lodges were to send in the names addresses \&c of all their Men by the 14th of April and again of their numbers and how many of the Lodges were houses of Call by the $22^{\text {nd }}$ in order that they may be able to regulate when to Strike. The Articles are nearly the same as I stated of the Bye Laws. A good deal of disappointment and dissatisfaction manifested itself among the Brothers at the delay of the Committee as to the Strike and several expressed themselves largely on this, but they were told by Brown and some of the Committee that we were not yet in a fit state to Strike both for want of Funds and numbers for many had joined who had not paid either their Levy or Subscriptions, at this a desultory conversation and some confusion took place of no particular importance amid which Fisher the President ${ }^{2}$ closed the Lodge and we separated about half past Eleven.-

Thursday April $10^{\text {th }} 1834$

Last night was our last at the Rotunda our initiations will be in future at the Union - Union St Whitechapel, The Blue Po[s]ts Brewer St Golden Square and the White Hart Windmill St Haymarket.-

1 With the King's refusal to act on the memorial and pardon the six labourers, the London Central Committee decided on and organised a mass petition to him. The Executive ordered a levy of $2 \frac{1}{2} \mathrm{~d}$ per head, of which $2 \mathrm{~d}$ would go to the six families, and $\frac{1}{2} d$ towards the expenses of the campaign. This raised $£ 555 / 9 \mathrm{~d}$ in London, and extended much wider than trades in the Union.

${ }^{2}$ Presumably Woodham had gone out in rotation. 
Tuesday Morning [22 April]

Sir/ I was yesterday a good deal among the Taylors at the Branch Lodges in the City. The Kings head St Pauls Church Yard, Bulls Head Jewin Crescent, Sun Londons Wall and the Ship in Lime Street. I found a great many about at these places and they all still seem very sanguine as to the Strike and wish it soon, but as yet from the causes I stated last week The Committee have not decided. Last night the Grand Initiation took place at the Peacock Houghton St Clare Market at which I attended when 103 were sworn as Brothers. Nothing new was stated nor will the Committees proceedings by known till Wednesday or Thursday. I shall attend to it and report.-

\section{V}

Friday Morning [25 April]

Sir/ I last night attended the Roebuck ${ }^{1}$ and found the Central-Committee have decided that a Special summons should be issued to all the Branch Lodges of the Trades Unions to meet to night, That every trade is to pay as a loan either $2 \mathrm{~s} / 6 \mathrm{~d}$ or as much as he can afford, to be repaid to him again. I being a small Master shall take the lowest rate, and as we are to meet to night I shall not be able to see you. I send this by Brand $^{2}$ and will thank you to send me as usual by him. The additional expence is $3 \mathrm{~s} /-$. They talk of a Strike on Monday and as I shall attend to night I will report by him to morrow - morning

Mr [name cut out]

\section{VI}

On Friday evening I attended my Branch Lodge at the Roebuck Duke St Aldgate. As I have daily sent notes to $\mathrm{Mr}$ [name purposely obscured $=$ Brand] stating that no positive determination was yet come to as to our strike, but when it did I would Report truly. On my attending at the same place on Thursday night, I found that no particular business would be done that night, but that the whole trade were es-

1 The Roebuck was the house of No 2 Branch Lodge, to which Hall belonged. The president was a foreman, Seagar, the secretary an Irishman, Michael Hayes, and the delegate, who attended the Grand Committee, was named Taylor.

2 Sometimes Hall saw Stafford or wrote direct to him, but often he reported through the policeman Brand. Brand's name is usually erased from the reports. 
pecially summoned for Friday night, to hear the decision of the Committee. On my going there I found the greatest assemblage of Brothers I have ever seen there. Previous to Taylor the Delegate coming Campbell the landlord stated that as it was expected by the Committee that Government would object to Public Houses being either Lodges or Houses of Call ${ }^{1}$ as well as the Masters it was intended to take Large Buildings, Chapels or upper Parts of Houses for the Men to work in when we strike. About half past Nine Taylor came and stated that the Committee had decided that we should strike this Morning - that every man who had work to finish should go and do so at his shop, but not take another job either cut out or basted up unless on the principle of the Master agreeing to pay the Wages and abide by the Rules and Laws of the Union as to time and Comforts which I have before stated. That every Branch Lodge should meet again at Eight O'Clock on Sunday evening to hear how they got on. That every man should be employed by the General fund two days in the week at $6 \mathrm{~s} /-\mathrm{p}^{\mathrm{r}}$ day, and if not so employed liberty to do what work he could get on his own account and be allowed 10s/ $-\mathrm{p}^{\mathrm{r}}$ week, but not to work for any Master struck against. That any Brother may work for another as he can afford to pay him. That all Brothers do pay to their Branch Lodges the most money they can afford as a Loan to be repaid to them in order to assist the funds, by the Work done by those unemployed. That as it was thought Equal Rights for all was our Motto no man would object to do all he could by assisting in this Loan and that no brother do enter his Lodge without giving his Christian [name] surname and place of Residence and his Card payed up to the end of March. He also stated having brought the proof sheet with him that the whole of the General and Bye Laws were in a last stage of being printed and would soon be ready for our use by purchasing and he hoped by Sunday. During the evening I went with a Brother named George Stokes downstairs and in the passage was a Soldier of the First Battalion of the $1^{\text {st }}$ Regiment of Foot Guards with his Side Arms on. He came with a Porter and another the first of which is employed two doors from Howards Coffee House in Dukes Place. Stokes shew him his Card when he said I know that well I Glory and so does our Regiment in your proceedings on Monday. ${ }^{2}$ If we had been called out we should all have Grounded our Arms. He has a broad

1 The magistrates could always bring pressure on landlords to refuse the use of their public-houses to radicals or unionists, by threatening to withdraw their licenses.

2 This refers to the great trade-union demonstration on 21 April, when 40-50,000 unionists marched in procession to present to Melbourne the petition signed by over 200,000 . 
Scotch accent and was tipsy. I shall attend to morrow night and Report on Monday.-

Saturday April 26th 1834

\section{VII}

25, Little Queen-street, April 25, 1834

SIR - By direction of the Friendly Society of Operative Tailors, I have to acquaint you, that in order to stay the ruinous effects which a destructive commercial competition has so long been inflicting upon them, they have resolved to introduce certain new Regulations of Labour into the Trade, which Regulations they intend should commence from Monday next; and I beg herewith to enclose you a copy of them.

As the demands there specified are of so reasonable a nature; and as, moreover, they are unquestionably calculated for the ultimate benefit of employers, as well as employed, the Society confidently hope that you will accede to them, and that henceforward a mutual confidence may be sustained between masters and men, and that their interests may be no longer separated, and opposed to each other.

It only remains for me to add, that your workmen, members of this Society, will cease to be employed by you, should you decline to act upon the new regulations; and further, $I$ think it right to apprize you that, in that case, they will no longer consider it necessary to support your interest; but will immediately enter into the arrangements prepared by the Society for the employment of such Members for the benefit of the Society.

I am, sir, your most obedient humble servant,

JoHn BRowne.

Secretary to the Grand Lodge of Operative Tailors

\section{REGULATION}

No Brother shall be allowed to work more than ten hours per day from the third Monday in the month of April to the last Saturday in the month of July; nor more than eight hours per day the remaining eight months of the year; and for such labour the remuneration shall be $6 \mathrm{~s}$. per day for the ten hours labour, which is to be performed between the hours of seven o'clock in the morning, and six o'clock in the evening; and 5s. per day for the eight hours labour, to be performed between the hours of eight o'clock in the morning, and five o'clock in the evening, out of which time, in either case, he shall leave his employer's premises one hour for refreshment. Nor shall any Brother work for an employer 
any where but on his (the employer's) premises, which shall be healthy and convenient, or on any other terms than by the day or hour. And no Brother shall be allowed to solicit employment, or to work for less than the regular wages within four miles of Covent Garden.

\section{VIII}

On Tuesday evening I attended my Branch Lodge No 2 at the Roebuck in Duke St Aldgate (I have attended there at the Regular Call-times since Monday Morning) and on going found that an order had been sent from the Committee that a special Meeting was to be held there at Six O'Clock but it was again determined that the Lodge Room was not sufficient for all of us and we again adjourned to the White Magpie. The Lodge was opened there about Eight and was filled to nearly suffocation and a long complaint was made by one party against the Secretary - Haynes - his own party supporting him, the result of which was that he wished if any complaint against him existed (none particular was stated) he would wish it to be sent to the Grand Committee and he would abide by their decision. A great deal of confusion and nearly rioting took place throughout this and it was at length agreed as he wished. From all I see or hear of the Complaint against him is that a party exists who wish their friend in his place and say of him that he neglects to mark those who do not answer to their names at call time. About Nine O'Clock Taylor the Delegate from the Committee came with his Report and read it. It was short and in substance stated that the Committee had heard of nearly 100 Masters who had ordered from different Lodges Men on our principles. That a Suggestion had been made a few days ago to the Central Committee of Trades Unions as to every Branch Lodge of all the Trades being made Taylors Clubs to be attended on their Lodge Meetings by one Delegate or more to act as Taylors taking orders and that they all have Clothes from no other persons but us thus keeping us as well employed as possible they subscribing according to what Garments they want, with this being sent to us we buy the Materials - make the Articles and after employing our men at our Wages we strike for the Profits to go to a Consolidated Fund for our support and for the support of any other trade that should strike. This the Central Committee have agreed to and it is to be made a law this week in all the Unions, they say that if our Masters hold out "this will defeat them for ever." that Mr Detrosier ${ }^{1}$ has agreed to lec-

1 Rowland Detrosier grew up in Manchester, where he was a deist, a radical journalist, and a brilliant educational lecturer to working men. He came to London in 1831, and was a leader in the National Political Union and the London Mechanics' Institution. He was attracted to Owenism, and acted as an intepreter 
ture at the Rotunda to night on the principles of Unions Gratuitiously for our benefit that one penny each is to be taken for admission, that none but Taylors be admitted and that all the Lodges - Taylors do meet at their Lodges at $7 \mathrm{O}^{\prime} \mathrm{Clock}$ and go from thence to the Rotunda to be there at 8 in procession as near as possible. That as the plan of having Clubs was to be resorted to those men who had not been able to pay up their Loan of $4 \mathrm{~s} / 6 \mathrm{~d}$ need not do so until they had work and then at $6 \mathrm{~d} \mathrm{p}^{\mathrm{r}}$ day, that already 1000 thousand [sic] Coal Whippers had stated that to be first they were ready anytime to give us an order for as many Jackets, that if any Master or deputy call at any Branch Lodge to compromise in any way not to answer them, but refer them to a Committee always sitting at the Albion in King $\mathrm{St}^{t}$ High Holborn. This being the substance of his Report a Desultory conversation of no importance took place and the Lodge closed to attend to night to hear Rowland Detrosier at the Rotunda and the business of Grand Lodge about 12 O'Clock.

Wednesday April 29th $[$ sic; 30th] 1834

\section{IX}

On Wednesday evening I attended at the Rotunda where the Grand Lodge of Taylors was held and at which as I stated yesterday Rowland Detrosier was to lecture on the Principles of Union. About $8 \mathrm{O}^{\prime} \mathrm{Clock}$ the Large Theatre was very full and in about half past Hundreds of Taylors was seen coming from all parts of London in branches but not in procession. Detrosier came about this time and there was not less than 3000 - Taylors present, indeed the place was so full you could not without much pressure obtain a place. The Lodge was then opened in the usual form and he began a Lecture verbally on first the Principles of Union which he took from the reign of Edward the $3^{\text {rd }}$, and in which he went to prove that from that time it had been the Maxim of Kings first Princes next, Aristocrated Noblemen next, Religion next, Navy and Army next and thus led to Middle men called Masters who all formed one Aristocratic Body to live on the labour which was the Property of the Working Man. His lecture was a very clever illustration (in his way) of producing the most determined hatred towards Masters and in which he justified us in our strike and implored us to keep steady in our plans and we were sure to succeed in obtaining that which was our

for the Saint-Simonian mission in 1833-34. In 1833-34 he lectured regularly at Owen's Institution and the Hall of Science in Finsbury. Crisis, August 1833 through March 1834; 12 April 1834, p. 5; G. A. Williams, Rowland Detrosier: A working-class infidel 1800-1834 [Borthwick Papers, No 28] (York, 1965). 
just rights. He then made a severe attack on the Times Newspaper for having in its leading Article in its Tuesdays Publication on us and designated the Writer as the most willing Prostitute to Power that ever existed. He then made a most furious attack on the Lord Chancellor for his speech as to trades Unions and stated that he had by the Union of the People been raised to his present situation and that since he had been in power had proved himself the most determined Profligate in Principle ever yet known. He strongly impressed on us not to put the least confidence in any professor of Principles, but to look to ourselves. He was listened to with very great attention and is to give Lectures weekly throughout the whole Trades Unions.-

Thursday May 18t 1834.-

$\mathrm{X}$

Friday Morning.- [2 May]

Sir/ I was yesterday among a great many Taylors and visited the Bulls Head in Jewin Crescent, I there found that "Nothing New" had been stated after I left the Rotunda. I went last night to the Roebuck to attend my call and all I could learn from Hayes the Secretary was, that the Committee were busy in collecting the different - Reports of the Newspapers as to our Strike in order to contradict them in the True Sun next Week. We are ordered to attend to night and Sunday night at the Roebuck to hear the Delegates Report from Committee, and thus we stand at Present. I shall attend and if anything occurs will Report it. I send this by Brand and will be thankful if you will send the money by him. Not that I immediately want it this morning, but I shall not be able to call on you this evening. I have paid since last Friday $4 \mathrm{~s} / 6 \mathrm{~d}$ as a Loan to the Union and with Pamphlets, Entrance Monies and Subscriptions my charge this week is $8 \mathrm{~s} /-$.

\section{$\mathrm{XI}$}

To THE GRAND

National Consolidated Trades Union

Whereas our Brothers, the United Operative Tailors of the Metropolis, being forced into their present position by the many grevious attacks and encroachments of the Masters, and we being fully aware of the great danger and inconvenience of large masses of Men remaining in Idleness,

We do therefore require that all and every of the members of the 
Consolidated Trades Union, do forthwith contribute the sum of one Shilling and Sixpence as Levy, in three payments, for the purpose of giving employment to the members of the above Trade. The first payment to be made on or before the $9^{\text {th }}$ day of May; the second payment to be made on or before the $16^{\text {th }}$ of May; and the third payment on or before the $22^{\text {nd }}$ of May, 1834: and further it is desired that all Secretary's will see the said money transmitted to Mr. E. C. Douglas, ${ }^{1}{ }^{213}$, High Holborn.

May $5^{\text {th }}, 1834$

By Order of the Executive Council

XII

Saturday 12 O'Clock [10 May]

Sir/ I have been from Nine to this moment at the Magpie, and have had to keep with many who are walking about. I find that No Money has been sent by the Committee except that last night Sixpenny Tickets were given by Freestone by order of the Committee to each Man for refreshments, and Hayes the Secretary has gone to the Committee for the Money. They are all still waiting and expect his arrival, but there is no certainty when they May get it.-

Mr. Stafford.

XIII

Wednesday Morning [14 May]

Sir/ I attended my Branch Lodge the Magpie last night and found there had been a Meeting of the Taylors at Owens Institution that day and that a Deputation from the Committee was to meet us there at Nine O'Clock, but up to Eleven no one came and though there was a great many waiting for their Money None came. Freestone kept us in suspense until that time and a great deal of discontent was manifested by the people waiting. We were at Length ordered to meet at the Bell in the Pig Market Smithfield at Nine this Morning, and the Hand and Shears-Cloth Fair. No Report was made, but it is expected the Committee will send one to us to morrow. Thus I cannot yet say how we stand, but will do so as soon as I can.-

1 The mysterious "Douglas" was the receiver of funds and petitions for the Executive. His existence is doubtful. 
Thursday Morning.- [15 May]

Sir/I attended at the Bell in Smithfield yesterday Morning at Nine and found that the only Report known from Committee was that every thing was going on well, This did not give any satisfaction and after a long discussion among about 300 Men we deputed Barnsley and Brown to go to Committee to know more and I with several others was walking the Streets all day waiting their Return. I could not get away from them $\&$ about Nine last night they returned and stated that all they could learn was that we were still going on well and that the Committee had no doubt but that we should obtain our Strike by Saturday Week, and impressed on us all to particularly attend our Branch Lodges to night to hear their full Report and what has taken place between them and the Masters at their Meeting Yesterday. We then agreed that those Men who had been drawn from the Magpie should join the Bell this Morning and as soon as possible move as a Branch Lodge in a Body to either the White Horse Cripplegate or the White Swan Coleman Street being more Central for the City. We are I assure you in a deplorable state. The only money sent yesterday was that the Secretaries of each Lodge was ordered to give each Man on the funds a ticket by which he could get Sixpennyworth of refreshment at the Bar and Sixpence in Money and the Men expect the same to day, but there is no certainty in that. I must therefore Report to morrow.-

\section{XV}

The Committee of Operative Tailors, 25, Little Queen Street, Holborn, Having received requests from various Masters, for a more explicit statement as to what security they would have, that a proper amount of Labour would be performed in the 10 hours, if they were to accede to us; we beg to say that it never was contemplated by us that an idle and inefficient Man should have this rate of wages, and for which purpose we had a regulation which we intended to have submitted to them, the Masters, for their concurrence, but being denied that friendly intercourse which we think should always exist between Master and Man, and in obedience to the above requests, we are now, or at any other time ready to shew a Statement of what Labour we were willing to perform in the 10 hours, to the whole of the Masters as a body or to any individual Master, that may think proper to demand the same, and for 
which purpose the Committee sit daily at 25, Little Queen-street, Holborn.

May 16, 1834

Signed on BEHALF OF THE COMmITTEE,

R. Stevenson,

A. O'Connell,

J. Elliott,

R. Pryer.

XVI

Friday Morning [16 May]

Sir/ I attended at the Bell yesterday the whole of the 8 Call Times and was about with many of the Men all day expecting the Delegate to come with the Committee's Report. He came at 5 O'Clock and stated that the Committee had been sitting all day on the Masters Proposals and was likely to continue so until late last night and that as he had to go to the different Trades Lodges to gather Money he could not attend last night but would come this Morning about Nine. I shall attend and either send you to day or bring what I have with me this evening.-

\section{XVII}

Tuesday Morning [20 May]

Sir/ I should have wrote you yesterday as to our funds and proceedings, but waited and am still without any real information on them. Up to Saturday night One O'Clock though numbers were waiting, No Money was sent and not until 10 on Sunday Morning with a promise that all would be paid on Monday Morning. The Men at the Bell in Smithfield received 3s/6d each - those at the Magpie 1s/6d. I have attended since I saw you to my Lodge and up to the last night 11 O'Clock No Money came, but at 4 in the Afternoon Fawne the Delegate came with an order from Committee that each Lodge was to depute three Men to meet at the Rotunda this Morning at Nine to meet a deputation from Committee to hear and know what was to be done with the Men. It is not certain when we shall see them to day but I shall attend to it and send again to morrow. A great many I find has seceded from us and I have no doubt many more will. ${ }^{1}$ We are I assure you in a very dissatisfied state and until we are in some way settled I cannot send you a Report. Many Projects have been started among us but Nothing is as yet settled.-

1 Although this is Hall's first mention of secessions, there had been press reports of some as early as 13 May. 


\section{XVIII}

The True Sun of last night has a long Article on our Trade and up to half past Eleven last night No Money was sent to the Lodge I belong, though it was promised at $5 \mathrm{O}^{\prime} \mathrm{Clock}$ and many was waiting. They at last decided to meet again this Morning. As to the Men going to work to Morrow Morning, from all I can learn No real decision has as yet been come to. I expect to hear more to night.-

Sunday May 25th 1834.

\section{XIX}

Sunday Morning [25 May]

Sir/ I had just returned from attending the Bell when I received your Note. At that place as I have before stated a great deal of confusion existed and a Report had been made as to Browne's resigning and absconding, but it is not true that he has Absconded. He has resigned in consequence of the Investigation Committee having found that he is deficient in the funds he has received and a further investigation is now proceeding in as to it, but from all I can learn No one knows the deficiency. ${ }^{1}$ It is said by some that $£ 400$. which was to be sent to Derby passed through his hands and has not been accounted for, but that has not been proved yet. He still says it has and it is still under investigation. As to the Robbery and Scramble for the Money the latter is not true. It is true that the Establishment was Robbed on Sunday last of 13 Coats (made) and Goods to the amount of $£ 70$. as well, and though the Committee applied to Hatton Garden they have not succeed [sic] in by their Officiers. In obtaining who did Rob the place, but from all I can learn two Men of the Committee named Walford and Stevenson are the only persons Suspected. As to the General Meeting; No such thing was intended last Night, but we are all ordered to attend our Lodges to Night at half past Seven. As to the Men going to work on Monday, it is not true that they have agreed to do so, but many have done so on the principle of $6 \mathrm{~d} \mathrm{p}^{\mathbf{r}}$ Hour and it still remains to be decided to night, What is to be done. I shall attend and Report to morrow.-

\section{$\mathrm{XX}$}

Monday Morning.

Sir/ I attended the Bell yesterday and found that about two O'Clock

1 Absconding officials were familiar enough in trade-union history. Browne denied the charge, and after several investigations he was cleared. 
yesterday the M... received 3s/6d each with a promise of more to day. We met again last night and from all that I can find The Men generally are going back to their Shops at the Old day work system $6 \mathrm{~d}$ the Hour very fast without the allowance of time, ${ }^{1}$ but it is expected that to morrow they will be ordered to Strike again for the time 10 Hours. All this depends on a Meeting of Delegates of all the Trades who are to meet at the Rotunda either to day or to morrow "to consult on our case". Browne is still at his house No 25 Great Queen $S^{t}$ and is to be met with at anytime. He says the Finance Committee are the Thieves and he is ready to meet them at any time to prove his Balance Sheet correct. This is still pending and as I shall attend to it I will Report.-

Monday May 26th 1834

\section{XXI}

During Monday I attended my Branch Lodge, but found Nothing new occurred except that a great many Men had gone to work and a great many seceeded from us. We waited until $\frac{1}{2}$ past Nine for our Delegate to Report the Proceedings of the Rotunda Committee when he came and Reported to us that they had broke up in consequence of not agreeing to the plans which the Masters have proposed as to the Men signing a Document not to belong to any Union, and that the other Grand Committee ${ }^{2}$ had ordered that at each Lodge on Tuesday night the Lodges were to send One Man each to still form another Investigation Committee. No further Monies came that day as promised, but more was promised on tuesday and I learnt from the Delegate and Secretary that though they last week as well as the others in Committee waited on many trades to get money the whole collected was $£ 70$ which was divided among the 31 Lodges. On Tuesday I again attended when Nothing new occurred until evening except that very few attended their Calls and it was well known that a great many had gone to work on the Old System and a great many had signed the document. About Nine the Delegate came from Committee and the Lodge was opened when instead of about 180 there was but 42 present. He had no Money and stated that the Committee had expected some from other trades

1 The meaning is unclear, but it seems to be that there was no restriction on the number of hours worked in the day, a prime objective of the union. In fact, many men went back at whatever terms were offered when they decided that the strike was lost. According to the Morning Herald of 31 May, 1400 went back at the start of this week and signed the document. Many of them accepted piece-work, which meant that they would earn much less than $6 \mathrm{~d}$ per hour.

2 I.e., the tailors'. 
but it had not come and they had not one farthing even to pay themselves at present, but they expected some to day. He stated also that the Delegates had no Report to make as yet as to Brownes Accounts, but were still sitting and that Browne had tendered his Resignation to the Executive, but it was not received at present until his Accounts were presented by the Investigation Committee and they had appointed - Douglas in his place. ${ }^{1}$ That Browne himself was to be examined by Committee to day which he has agreed to and that we were requested to attend a special Lodge to night. He brought a Resolution with him for us to pass which had been passed at a General Meeting of all the Trades of Steel, Iron, farriers, Engineers and others who are in London which had that day sent a Deputation to our Committee stating that they were determined to support us if we kept up the Strike by Striking themselves. There is in their Union about 8400 in Town and the Country who include all the above branches (they have a Lodge at the Bell) ${ }^{2}$ and there is but 8 of those Trades in London who are not in Union. They say particularly an Engineer named Reynolds that if we are firm (he is one of the Principles) They shall Strike and in one week or two they will stop "All the Commerce and Trade in London and all the Bloody Towns in the Country for they can see that the Masters and the Government are determined to put down the Rights and Liberties of the People." We passed the Resolution which was also read in other Lodges and agreed to meet in Lodge again to night.-

Wednesday May 28th 1834.

\section{XXII}

During Wednesday I attended the Bell in Smithfield and the Sun in London Wall - two Branch Lodges where I found that Nothing had occurred more than fresh Reports of many more of the Men leaving us and going to work on the old system and of many signing the Masters Bond who had gone to work. About 8 in the evening our Delegate came to the Bell where not more than 20 met. He stated that he had no Report from Committee as they had heard of many of the Men having gone to Work they were still sitting on what was to be done and he expected they would be so all the week. He brought No Money, but

1 See p. 94, note 1. This is the only mention of Douglas as a person, and it is not based on direct knowledge. The name first appears as an official of the Union in Pioneer, 22 March 1834, p. 260. It was probably a pseudonym; cf. Galton, The Tailoring Trade, p. lxxxiv; Oliver, “The Consolidated Trades' Union”, p. 80.

2 This was a lodge of whitesmiths. The Bell would long be a centre of engineering trade unionism in particular, and London trade unionism in general. 
thought he should be able to do so by Saturday. The Committee requests that all the names and residences of the Men who keep out be sent them in order to know our number by Saturday Morning. The Finance and Investigating Committees are still sitting examining Brownes Books and Papers and he is with them and from all I can find there is several who think he has been Guilty of some Embezzlement and several do not. It is expected they will sit until Saturday at least.-

Thursday May 29th 1834

\section{XXIII}

During Thursday and up to Five O'Clock on Friday evening I attended my Branch Lodge the Bell in Smithfield and several other Lodges The White Magpie Skinner St Bishopsgate - The Sun in London Wall the Pauls Head Pauls St Finsbury and The Three Tuns Smithfield, at all of which Places I found that a great many Men had gone to Work on the Old System of Working many of whom had signed the Masters Bond and others had got work where no Bond was necessary and have seceeded from us not having been able to get the Promised Money. I find this is the case also at the West end of Town. About the above time The Delagate came from the Committee to the Bell and stated that the disposal of the Funds expected to be received from other Trades to morrow (Saturday) was taken out of our Committees Hands and are to be placed in the Hands of the Executive, or the whole of the Trade Union Committee and that it was fully expected by to morrow night that each Man who still stood out would get the whole Money due to him. He stated also that the Executive had heard the Masters of all the Trades were to hold a Meeting at the London Tavern on Saturday evening that is those Masters who employ Men belonging to the Union "and as many more as they could persuade" to join them in forming a Union for the purpose of not employing any Unionist who would not sign a Bond to seceede from it - and a Security for his not doing so again. ${ }^{1}$ They the Executive have therefore ordered a Meeting of all the Delegates and Secretaries of all the Trades on Monday next to determine whether there shall be a General Strike of all the Trades in Union

1 This refers to a meeting of master builders at the City of London Tavern, partly to consider reducing wages. Poor Man's Guardian, 24 May 1834, p. 130. After defeats in the country, London was now the only remaining centre of power left to the Builders' Union, and the employers were planning a confrontation. This came in August with the presentation of the "document"; a fierce struggle ensued and the Builders' Union was shattered. 
immediately, or what else is to be done, and on their decision depends whether we hold out any Longer.-

Friday May $30^{\text {th }} 1834$

\section{XXIV}

During Saturday and Sunday I attended My Branch Lodge - the Bell in Smithfield. All day on Saturday the Men were waiting for Money from the Committee, but none came. On Sunday Morning at Nine Griffin the Delegate came and stated that all he could get for them was S45 and that he did not (with all the other Delegates from other Lodges) get until near Three O'Clock on Sunday Morning. This was not enough to pay the Landlord for what Beer and Bread and Cheese Knight the Secretary had been answerable for during the week for the Men and Griffin borrowed 8s/2d from the Lodge of Smiths held there. Thus the Men got no money at all, but were promised that as the Delegates of all the Trades were to meet to day at $2 \mathrm{O}^{\prime} \mathrm{Clock}$ at the Rotunda they would have Money either to night or to morrow night. In the evening I was with Griffin Delegate of the Bell. Travers of the Sun London Wall Campion of the Pauls Head Finsbury and Freestone of the White Magpie Skinner Street all Delegates and from them I find that at their Lodges the Men are very dissatisfied at not getting their Money and are determined to day to leave and get Work where they can. They say also that they have no doubt but that the Delegates at their Meeting to day will decide that we must give way to the Masters, but it is not likely their decision will be known until Lodge night to morrow (Tuesday) night.

Monday June $2^{\text {nd }} 1834$

\section{XXV}

During Monday I attended My Branch Lodge the Bell in Smithfield and we expected our Delegate Griffin to come to inform us as to the decision of the Trades Delegates, He came about half past Ten last night and stated that at present the Delegates deliberations was in our favour, but they had adjourned to this day and we were to have their Report through All the Branch Lodges to night. I shall attend and Report to morrow.-

Tuesday June $3^{\text {rd }} 1834$

\section{XXVI}

On Tuesday evening I attended My Branch Lodge the Bell in Smithfield. (It was Lodge night with all the Lodges in our trade throughout 
London.) There were present 86 Men to hear the Delegates Report. About half past Nine he Griffin came and stated That the Committee of the Trades Delegates who had met at the Rotunda had decided that rather than we should fail in our Strike for want of funds Every Member of their Trades in the Union who are in Work should give One Days Wages $\mathrm{p}^{\mathrm{r}}$ week to support us which they calculate would be at least $£ 6000 \mathrm{p}^{\mathrm{r}}$ week, and that each Taylor at Work on Honourable terms should pay $1 /-\mathrm{p}^{\mathrm{r}}$ day to the Funds out of his Wages all of which monies shall be paid to the Executive Council for them to distribute to our Committee for the Men Weekly who still stand out and this they promise to do for Twelve Months. They also examined the Books of Browne the Secretary. the Finance and other Committees of our Trade [met] and passed a Resolution which is in the True Sun of last night which states that there is no truth in the Report so much circulated of Embezzlement of the Funds and that all the books and Papers have been proved to be correct. Our Committee instead of sending their Report to the Lodges last night have ordered a Meeting to be held of all our Trade who are out to day at two O'Clock at Owens Bazaar in Charlotte St Fitzroy Square to hear the Report and sent a special order through the Lodges last night for our attendance and that No one would be admitted without the New Pass Words. To the first Tiler, "Yet." To the second - "Firm." I shall attend and Report to Morrow -

Wednesday June $4^{\text {th }} 1834$

\section{XXVII}

On Wednesday at two O'Clock I attended a Meeting of Journeymen Taylors at Owens Bazaar No 14 Charlotte St Fitzroy Square. Called by the Taylors Committee to Report the Proceedings of the Delegates of All the Trades in Union in London who met at the Rotunda on Monday and Tuesday last to consider what was to be done in our case. By the above time about 3000 Men met and soon after the Committee with Browne our late Secretary having arrived - Jenkins was called to the Chair. He stated that at the Delegates Meeting on Monday all the other Trades in Union by their Delegates had agreed to propose to their Trades that in order to keep up our Funds and defeat the Masters Bond (knowing as they did that the Masters of all Trades were forming a Union to make all their Men sign a Bond similar to ours and which was to take place on the $10^{\text {th }}$ of June) they proposed that All the other Trades in Union should give One days Wages support Weekly to us. This was for our decision as to accepting the offer to keep us out which was agreed to unanimously by us and they are to Report to our Com- 
mittee on Saturday how such Proposition will be received by the Lodges of their Trades during this Week. A long and confused conversation took place by several of the Committee speaking on this subject some of whom thought it was useless to stand out any longer depending on such promises as this and one - Newby proposed that a special Lodge Meeting be called that night to know the opinions of the Men through the Lodges as to their seceeding at once or waiting the Delegates Report on Saturday, but Stevenson proposed a Resolution of the Committee That No Secession or difference do at present be allowed to exist in the Lodges, but that we do wait the Issue of Saturday, and if not favourable to us we should withdraw from the Consolidated Unionkeep our Lodges still and do the best we could as a Body of ourselves and this was carried Unanimously. Another Resolution That we give no concession to Masters from our Original Bond was put and carried also. Another that the Men do still keep attendance on their Lodges particularly this Week, to still keep firm in order that if we fall We will fall Nobly. This was also carried and after a good deal of confusion by the disagreement of the Speakers in their opinions A Vote of thanks was voted to the Chairman and we separated at Five O'Clock. From what I found among the Men there and at several of the Lodges I have attended, Very Great dissatisfaction and no great expectations exists as to our keeping out after next Saturday. A great many present will not wait longer than that time and many not till then. We have been so bouyed up with promises that it is no longer believed we can exist in longer keeping out. We have and still are decreasing fast in Number by Men going to work daily and from all I can see we cannot keep out but a few days longer having No Funds and scarcely any of the Promised Funds of the other Trades to support us. Browne tried to Vindicate the "Calumny" so much heaped on him, but was not allowed to speak much. $\mathrm{He}$ is not now charged with Embezzlement, but with being the cause of our Striking prematurely and saying he had the Sanction of the Consolidated Trades Unions in doing so whereas it had been proved he had not, for this he is much hated and blamed for our failure if we do fail.

Thursday June $5^{\text {th }} 1834$

\section{XXVIII}

Since I wrote on Thursday last I have continued to attend to the proceedings of our Strike and should have wrote before, but as I then stated we were to wait until Saturday night or Sunday Morning to know what decision the other trades had come to as to their Delegates plan at the Rotunda Meeting, and what Monies was sent from them for 
our support. Our Committee (Taylors) sat nearly all day on Saturday and up to near 12 on Saturday night they had received No positive decision as to our being supported and all the Money received was £152. This they sent by the Delegates to their Lodges and which amounted to $2 \mathrm{~s} /-$ each $\mathrm{Man}^{1}$ with a promise that they would have more on Sunday Morning and that each Lodge was to meet on that Morning at Nine O'Clock. They did meet and about Ten they each received Sixpence. At this the Greatest dissatisfaction prevailed and in all the Lodges the Men declared they would wait no longer and get work $w[h] e r e$ they could under any circumstances. They were also told that a General Meeting of the Trade would take place on Monday Morning at Owens Institution in Charlotte $\mathrm{S}^{t}$ at $8 \mathrm{O}^{\prime} \mathrm{Clock}$, but in the evening this Meeting was put off to join the One at 5 O'Clock of all the Trades at the same place as Advertised by order of the Executive in Placards and in the Trades official Gazette which I sent on Friday. During Monday I visited with others many of the Lodges of our Trade and found in all of them that a great many of their Men had left in disgust and had gone to work. About Five O'Clock I attended at Charlotte $\mathrm{S}^{\mathrm{t}}$ where about 2000 Members of different Trades met among whom was several Women (the smallest Meeting I have ever seen there and still less of Taylors.) About Six Goldspink ${ }^{2}$ one of the late National Union Committee was called to the Chair and Mr Owen read Six Resolutions the Executive had framed for the Meeting the substance of which was that as the Masters of all the Trades had determined to do away with Unions by not employing Men who would not sign their Bond the Unions seeing the distressed state Men with Families were in should pity those who did so and that a Meeting of Delegates of all Trades throuhout the Kingdom should be held in London on the Blank Day of Blank Month to deliberate how to supercede the Signing such Bond. Owen in a long speech proposed these and George Petrie who has just returned from the Country seconded them. Petrie has been several weeks in all parts of the Country Initiating Taylors (I stated when he went) and I find from him that "the Spirit of Union in the Country is very strong, but their Funds are very weak." A Great deal of confusion existed in the Meeting by several Taylors charging the Executive with Misleading them and long before the Meeting broke up many left in disgust. Savage, ${ }^{3}$ Neesom, Stevenson, Lane and others addressed the Meeting

\section{This suggests a total of 1500 strikers.}

2 Thomas Goldspink, an ex-committeeman of the NUWC, was a carpenter, and a leading figure in the Builders' Union and the Central Committee.

3 There were several radicals called Savage, but this is undoubtedly John Savage, who when a linen-draper had been the leader of the Marylebone parochial reformers who gained control of the vestry. He was an early member of the 
on the necessity of still keeping in Union and all I could learn from our Committee was that they are to sit to day to settle what we can now do and as this is Lodge night through all our Trade in London they expect to decide and Report to all the Lodges. From this and from all I see daily I am certain that our Strike may now be called lost and those who propagated and have had the Management of it are blamed, Marked and will never again be depended on on this or any other occasion.

Tuesday June $10^{\text {th }} 1834$

\section{XXIX}

On Tuesday evening I attended and was appointed Vice President of my Lodge of Taylors - the Bell in Smithfield. As I stated yesterday all the Lodges were summoned to meet, and in continuance of my Report yesterday as to the secessions of our Men instead of 182 who were Members of this Lodge 21 only attended. About Nine O'Clock Griffin our Delegate came from Committee and all he had to state was that they the Committee had ordered all the Lodges to decide two Motions. The first was "Whether The Taylors should secede from the Consolidated Union and form a Union of themselves," and the second was whether we should still keep out until next Saturday and wait to see what the Trades would do for us. Both these were carried, but still the Men present were determined not to trust them any longer. Thus we remain depending on the Decision of Committee and from all I can see I shall not have to Report until after Saturday. I however shall attend and amid the confusion we are in I doubt not, but before this week ends our Strike will end.-

Wednesday June $11^{\text {th }} 1833$ [sic; 1834]

\section{$\mathrm{XXX}$}

On Tuesday evening I attended my Lodge of Taylors at the Bell in Smithfield. In my Report yesterday I stated that Our Committee was to Report to our Lodges the Decision of the Executive as to supporting us in our Strike. Up to Ten O'Clock No one came, but at that time Brindley the Delegate of the Sun in London - Wall, Griffin the Delegate and Knight our Secretary came and stated to us that our Committees had not received that support from the Consolidated Union as

NUWC, active in reform agitation, leader in 1833 of resistance to the Assessed Taxes, and on the first committee of management of Owen's Labour Exchange. In 1834 Savage was a publican, his house being a great radical centre. 
they expected and advised that the City Lodges should form themselves into Districts of 100 each so as to be prepared to form 1000 to be at the command of the Committee to divide them either to Work in the City or the West end of Town. There was but 18 present and those amid the dissatisfied manner as to not being better supported created great confusion and the consideration of those propositions were adjourned to Thursday Night. Griffin our Delegate who was Foreman to $\mathrm{M}^{\mathrm{r}}$ Stafford - the corner of long lane in Smithfield has now left our Strike and gone to work for Mr Solomans in the same Lane and proposed myself to be the Delegate of the Bell and recommended us all to go to work under any circumstances. I expect to have to attend Committee as his motion was agreed to as to me and when I do so I shall then be able to give a more faithful Report of our Proceedings than from the confused manner we are in than I have done.-

Wednesday June $17^{\text {th }}$ [sic; 18 th $] 1834$

\section{XXXI}

In my Report on Saturday I stated that on Monday I would Report as to the Proceedings of the Union, but I have not since I stated in my Report last week received a Note from Griffin that I then stated I expected. I have not been able to see him to converse with him until last night and I find from him that the Whole Builders Union through their Secretary Wilcox had decided up to One O'Clock on Sunday Morning that they had No Funds to support our Trades Strike (Taylors) and that their Committee had decided that we had better get work in the best way we could. At several other Lodges of our Trade I find this is acted upon and not having One Farthing sent to them from the Executive last Saturday night many of the men at the Lodges are so exasperated that they are determined to revenge themselves on the Committee Men. As to our Trade Committee Griffin our Delegate says he has totally left them and instead of myself put Staples in his place, and that we are to know their as well as the intentions of the Union or Executive to night - Lodge Night.

Tuesday June 24th 1834

\section{XXXII}

From all I have seen or heard since I wrote on Thursday as to the Consolidated Union and particularly as to our trade (Taylors) I do not see that $I$ have any thing of any importance to state of it. We (Taylors) as I then stated had withdrawn from the Union and our Committee are 
still trying to form a Union of our own trade, but as yet Nothing has been positively done. There are now a few Men who remain at the Lodges we used to meet at in Union which are considered Houses of Call, but from all I can learn very few calls for Men come to those Houses and I account for it by knowing that five out of every six who struck have got work wherever they could under any circumstances and are determined not to join any Union again. Thus, though my Reports have lately part through illness been not so frequent as usual I am certain that what I now state is the truth and that as I first stated The Union would fall. New projects are in agitation in many places and opinions in the old Members of the Union, but from all I can see and I beg to again repeat it $I$ do not at present see anything of importance to Report.

Friday July $4^{\text {th }} 1834$. 